\title{
The Nature of Revolution on Animal Farm
}

\author{
Goran Omar Mustafa ${ }^{1}$, Rebin Najmalddin ${ }^{2}$ \\ University of Halabja, IRAQ \\ e-mails: ${ }^{1}$ goran.mustafa@uoh.edu.iq, ${ }^{2}$ rebinan@outlook.com
}

\begin{abstract}
Revolution as a phenomenon is considered as a way to a complete change of a situation or system of government to a better one. Is revolution really the right way to fulfil our dreams and have a better way of life? Or is it simply just changing the face of rulers or the name of the governments? Many writers and novelists have written about this issue. George Orwell, who is considered as a political writer, is one of them. He wrote many novels. Animal Farm, as one of them, is an allegorical story of some animals on a farm. They begin a revolution against the humans with the dream of getting rid of Man as the root cause of their problems, and to be rich and free. They have a short period of honeymoon revolution, but then their dream of building a utopian farm is crashed by the pigs and they would find themselves in dystopia. This paper aims to study the nature of revolution generally to shed light on human history, Then to explore how this phenomenon is treated by Orwell in his novel. Can we consider revolution as a right way to have a complete change in the political system and thinking of people? The researchers try to illuminate and find answers for those questions by providing examples from the story of Animal Farm.
\end{abstract}

Keywords: Revolution; Animal Farm; Animalism; Utopia; Dystopia.

\section{THE NATURE OF REVOLUTION}

Our history has always been a story of revolution and reform. Regardless of the conditions or the environment we have always had our share in the uprisings and conflicts; which has led to social change toward better or worse conditions (Bin Uzayr, 2013). These revolutions have been important elements for the creation of this modern world. The concept can have different interpretations from transformative, or radical change, to depicting different phenomena from the "Industrial Revolution" to the "Sexual Revolution". From history we can say revolutions have referred to violent movements set out for the purpose of bringing down one regime through a process which influences radical change in all governmental and societal institutions. From the French Revolution of overthrowing the monarchy onward, the concept has become more of a synonym of radical reform of the past. It became a public knowledge that modernity can only be achieved through radical and violent transformations (Neitzel, 2018).

According to Hanna Ardent the modern understanding of revolution is that something new, a new era and story is about to unfold, in fact people came to this realization after the two renowned revolutions of the 18 th century. And in its early stages none of the actors had any prediction of what's going to happen next, or how the drama is going to end (Hannah, 1962).

As Huntington (2006) believes those revolutions won't happen suddenly or directly but it is rather more of a scale of conflict intensity; from the revolutionist's strength or strategy, to the governmental organization. For example, revolutions rarely happen in countries who have good organization of their institutions like Switzerland, Germany, or the United Kingdom, but it's more likely to occur when people understand they are impoverished of their rights by the government, or when people push to modernize their society (Huntington, 2006).

Venter and Bain (2015) state that in the early stages of an uprising it's possible to have a peaceful revolution, a revolution without violence as given by Marcuse's theory, but this theory goes opposite to the known definitions of revolution. However, we did have peaceful revolutions in Tunisia and Egypt during the Arab Spring, until religious groups merged in and eventually the events led to violence (Venter, 2015).

In his book "The Anatomy of Revolution" Brinton made a comparison between revolution and disease in which we can summarize the whole cycle of revolutions in. He suggested that revolution resembles 
a disease with a high fever, "As new desires arise, or as old desires grow stronger in various groups, or as environmental conditions change, and as institutions fail to change, a relative disequilibrium may arise and what we call a revolution breaks out" (Brinton, 1965, p. 16). Similar to a body responding to a disease and recovering to its first condition; similarly, revolutionized countries attempt to recover their original conditions before the revolution happened. Brinton pointed to this as the main factor behind the failure of revolutions, or not achieving its stated goals. For instance, after the French Revolution in 1815, the French returned to monarchy despite the goals of the revolution (Brinton, 1965).

Mandel (1989) explained that normally revolutions start when the people become aware of their rights, refuse to be controlled anymore, and acknowledge the fault in their rulers. With the recognition of this stage people can transform into mass mobilizations quickly, from helpless individuals to freedom fighters, Starting strikes and organizing mass demonstrations against their oppressors who are shielded with armed forces. The persistence, sacrifice and heroism of the revolutionists lead to the first triumph of revolution which is disintegrating their rulers. And the final glory of revolution is when the armed forces of revolution is replaced to that of the former rulers (Mandel, 1989). At the same time, Brinton added that revolutions become real after winning over the military forces of the government, and after that comes a period of peace by the moderators; which he calls the honeymoon period (Brinton, 1965).

Brinton (1965) reported that the honeymoon is but a short ruling time by the moderators and won't last long as various cliques among revolutionaries show up. Usually the moderators are the known figures of the old opposition against the government like the richer or higher placed people; and it's only considered from them to take over the government (Brinton, 1965).

Another problem with revolutions, or governmental system is praetorianism, as Huntington (2006) mentioned, "Praetorianism refers to the intervention of the military in politics." In underdeveloped societies, politics and governments lack independency and cohesion; all social institutions engage in politics. Countries with political armies also have political clergies, political universities, political bureaucracies and political labor unions. The problem with the politicization of social forces is the open confrontation of power, with no accordance to laws or court systems; which is caused by weak government structure. Thus, no agreement exists among these forces as the main method for resolving conflict.
Consequently, this results in the intervention of military in politics in the form of a military coup (Huntington, 2006).

According to Mandel (1989) As the nature of revolutions, the starting point is when the people feel weak before their rulers despite their superiority in out numbering them. Overcoming this feeling of weakness is the precise point of starting revolution, when the people all refuse to kneel anymore and think "We won't take it any longer". And the truth about societies is as what was stated by Abraham Lincoln: "You can fool all of the people some of the time and some of the people all of the time. But you cannot fool all of the people all of the time." However, going against the political and social challenges locally and regionally is simply the nature of revolts; and these revolts become revolutions when the whole nation is unified (Mandel, 1989).

Huntington (2006) separates two "patterns of revolution" which are Eastern and Western revolution. The sequence of events in the Western pattern starts with collapse of political institutions, and then various groups assemble with political view in benefits. The Eastern sequence of events start with the occurrence of various new groups with the goal of collapsing the current regime (Huntington, 2006).

Revolutions will stay as facts of life because of the paramount nature of political power, its production and relations. More reasonably because these relations are rooted deep, and each ruling class resists the termination of this relations, until a revolution emerges in as a tool for overthrowing these relations (Mandel, 1989).

Stewart (2002) believes that history tells us that the societies that went through revolution are still suffering conflicts and struggle over one issue or another. We can argue that fundamentally the transformations in revolution leaves after itself a negative outcome on the social and economic aspects of that society and it takes a lot of time for that society to recover or develop toward better (Stewart, 2002).

\section{WHY DO REVOLUTIONS OCCUR?}

It's crucial to recognize the main reasons behind the various revolutions in history. Though it's not possible to point out one mutual factor as a main reason behind those revolutions, but it should be mentioned that not all revolutions occur because of class conflicts. It can be one of the factors, but generally it's not the whole story. It's been theorized that political conflict conditions are the point where revolutions spark, then political movements become the revolutions social forces ("Revolutions...", 2015). 
In one of his books, Lenin (1920) identifies four general condition in which a revolution might happen which can be applied to both social, and political revolutions. He explained the basic rules of revolution, which has been affirmed by revolutions in general and more especially the three Russian revolutions of the twentieth century, and they are as the following: in order for a revolution to start it's not enough only for the burdened people to realize they can't take it any longer, and require changes, it's necessary that the oppressors, the rulers should not be able to continue the old way. The crisis should affect both sides, a nation-wide crisis is when the lowerclasses refuse to live the same way anymore and the upper-classes cannot preserve in the same way; here a revolution can triumph (Lenin, 1920).

It's also necessary that the majority of the workers and the thinking-class understand that a revolution is utmost necessary and should be ready to fight and make great sacrifice. Turmoil amongst the middle class is another necessity; a situation in which the middle class is wavering between the working class and the capitalists. Moreover; among the proletariat a revolutionary party and leadership should raise and grow, and the armed forces of these revolutionists should be at its advanced stage (Lenin, 1920).

DeFronzo (2018) pointed out that the reasons that impact the progress of a revolution include inequality and depriving society, the extent to which the society is divided, foreign interference, loyalty of the armed forces. Out of these factors, five elements play crucial roles in the development of revolutions and, if occurring simultaneously, make up a sufficient condition for the success of the revolution; according to the studies of renowned scholars, those factors are "Mass frustration resulting in local uprising, Dissident elites, Powerful unifying motivations, a severe crisis paralyzing state administrative $\&$ coercive powers, a permissive or tolerant world context" (DeFronzo, 2018).

The attempt of all these revolutionists either from social, political, or religious revolutions, was their insistence of having their heaven, here, now, on earth. An eagerness to conquer evil once and for all.

\section{REVOLUTION ON ANIMAL FARM}

Orwell's work Animal Farm is considered a unique novel for political satire and allegory. The novel is known to be a Marxist novel, all the characters in the novel share a common goal toward change, throughout the novel the writer attempts to depict the living example of oppressed and impoverished masses attempting to bring about a classless society.
And the endeavors for creating an ideal society on peace, equality, and a life of harmony for the animals, at the same time presenting serious critique on Stalin's regime, and communism ("How is...", 2013).

The first stage of the Animal Farm revolution starts with the Old Major's speech to the animals of the Manor Farm, what we can draw from his speech is that he has great potential in the farm, since "everyone was quite ready to lose an hour's sleep in order to hear what he had to say" (Orwell, Animal Farm , 2013, p. 1). He passes on his experience to the animals and emphasizes that he has had " a long life ... had much time for thought .... I understand the nature of life on this earth as well as any animal now living " (Orwell, Animal Farm, 2013, p. 3) Experience and knowledge gave power, reputation and high position to Old Major among the animals. He used all together to stimulate the animals and think about their life under the tyranny of human beings.

Language plays an important role in the play. Elbarbary (1992) believes the revolution in the novel focuses on the language. Through language the pigs, from Old Major to Squealer, use language to stimulate the other animals to rebel against Mr. Jones. And when the revolution succeeds they use language to control the mind of the animals and accept the tyranny of the pigs (Elbarbary, 2009). Form the beginning Old Major utilized language techniques and rhetorical strategies to even more emphasize on encouraging the animals and stimulate their feelings. The Animals need to be aware of their tough life and how they are manipulated by human beings in order to rebel. So he goes on by asking the cows "You cows that I see before me, how many thousands of gallons of milk have you given during this last year? And what has happened to that milk...? And you hens, how many eggs have you laid in this last year, and how many of those eggs ever hatched into chickens?... And you Clover, where are those four foals you bore...?" (Orwell, 4). These questions rhetorically present the injustices that have been done to the animals by Mr. Jones, the owner of Manor Farm, and by focusing more on the individuals Old Major could get into the mind and heart of the animals and strike feelings of resentment in them ("How Effective...", n.d.). Old Major tries to let the Animals know that their conditions need to be changed to a better one. Also the animals need to be aware of their tough life in Manor Farm.

Old Major is the sound of disapproval against Mr. Jones, demonstrating Jones's tyranny toward the animals; his carelessness and killing the animals when they grow old or weary ("collaps of...", 2004). The Owner of Manor Farm, Mr. Jones, is also the villain 
of the story. He is the one that leaves no option for the animals except rebelling. He is a drunk incompetent farmer, he leaves out the animals, does not feed them, and is careless. Quotes from the novel would depict this. "Mr. Jones, of the Manor Farm, had locked the hen-house for the night but was too drunk to shut the popholes" (Orwell, Animal Farm , 2013, p. 1). This shows how careless Jones is for the wellbeing of his animals, he neglects them and is too drunk to close the popholes, and by leaving it open, the chickens would get cold. In addition to his carelessness, he is also a cruel farmer, "As for the dogs, when they grow old and toothless, Jones ties a brick round their necks and drowns them in the nearest pond" (Orwell, Animal Farm , 2013, p. 5). Old Major tries to show the animals that Mr. Jones is not a good and careful owner that takes care of the lives of the animals. By the Example of the old dogs he wants to give a concrete example about the brutal and violent behavior of the owner. Mr. Jones as an owner should treat the animals well and look after them any time they need, but he is doing just the opposite.

Mr. Jones's cruelty and tyranny is an image of oppressors and dictators, who don't care for his people, and the development of his country. It's Jones's brutality that the animals revolt against. They are obviously frustrated with their living situation. Now two main factors exist to start the revolution. First Mr. Jones as the owner no longer has the ability to provide a good life for the animals and he is irresponsible. The second one is that the animals are aware of their bad condition of their life and they cannot bear it any more.

After the Old Major's speech, the animals revolt against Mr. Jones and kick him out along with the rest of humans of the farm. Next, the name of the farm is changed from Manor Farm to Animal Farm, and they brought about a set of rules called 'The Seven Commandments' for everyone to obey and live by. Soon after, the pigs thought about running the farm by themselves and taking control over the rest of the animals. Napoleon, who is the powerful pig, succeeds in manipulating the animals through his strategies, and in the process he himself turns into a manipulative dictator (Weir, n.d.). Napoleon through his mouthpiece, Squealer, manipulates all the animals' mind and very easily can persuade them to follow or obey Napoleon. Squealer is famous for turning black into white among the animals.

The revolution's honeymoon period of the farm goes well, the animals live happily together, living a much better life than how they used to live in times of Mr. Jones. Not after so long, the inequality between the pigs and the other animals begin, when Napoleon and other pigs steal milk and take extra apples for themselves and tell the animals not to complain about the inequalities they see between the pigs, the brain workers, and the animals because if the pigs fail in their duties Mr. Jones might return. And that was enough to persuade them ("plot...", n.d.).

Day after day the utopia of the animals turns into a dystopia. Radical changes happen, the Seven Commandments which were once thought of as good rules to live by now has all changed. The pigs change the rules the way they want mostly in favor of Napoleon. "No animals shall sleep in bed" is changed into "No animals shall sleep in bed with sheets" they take advantage of the animals' illiteracy and replace all the rules with new ones like "All animals are equal but some are more equal than others". In the further steps the animals' society is divided into two classes, the pigs and dogs as superior, and the other animals in the lower class (Johnson, https://freebooksummary. com, n.d.

Evidently the animals lack education and selfconfidence in spite of the active role which most of them played in the first rebellion. Orwell is not implying by this the hopelessness of a proletarian revolution: he rather points to the need for education and self-confidence in any working-class movement if it is to remain democratic (Letemendia, 1992). Orwell may want to depict that the only guarantee to have a better life after revolution and not to let it derail is to have educated and literate citizens. Otherwise they will be manipulated and let the ones in power to be dictators.

Things get worse, animals are enslaved by the pigs and dogs, more work to do with less food. "Throughout the spring and summer, they worked sixty hours a week, and in August Napoleon announced that there would be work on Sunday afternoon as well. This work was strictly voluntary, but any animal who absented himself from it would have his ration reduced by half' (Orwell, Animal Farm , 2013, p. 39). This extra work was put on the shoulder of the animals while the pigs themselves they had a very luxury life and the gap between them and the rest of the animals becomes wider.

The animals' fate seems mirror rather closely that of the common people as Orwell envisaged it some six years before commencing Animal Farm:

"what you get over and over again is a movement the proletariat which is promptly canalized and betrayed by people at the top, then the growth of a new governing class. The one thing that never arrives is equality. The mass of the people never get the chance to bring their innate 
decency into the control of affairs, so that one is almost driven to the cynical thought that men are only decent when they are powerless." (Letemendia, 1992, p. 1).

At first, Napoleon was actually one of the three pigs who were the founders of "Animalism", based it on the ideas of the Old Major. Animalism is the system of ideology that encourages animals to revolt. Napoleon was not in any way talented, but he knew well how to make things go his way. He made good use of various techniques and strategies, just as politicians. He won the sheep's support, whenever they find complaints from the other animals, all together shout "four legs good, two legs bad" so as to prevent others make any speech. From the beginning he took nine puppies from their mothers and looked after them, when they grew up he used them as tools to take control of the farm (Napoleon, n.d.).

Napoleon exercised radical power and violence to hold his position in the farm. For instance, he took the puppies and raised them up, not to educate them for their own good, but to take advantage of them. He used them to overthrow anyone standing in his way, and protect himself from any danger that he may face. He was even disloyal to his comrades and planned to kill anyone that he considers as an obstacle in front of his ambition to get absolute power. When he is in disagreement with Snowball, one of the three main pigs, over the issue of the windmill, Napoleon's well trained dogs come in and they try to kill him. But he could escape at the end. Napoleon had his dogs banish him from the farm and later called for killing the traitors who had leagued themselves with Snowball.

Orwell himself in one of his letters to Dwight Macdonald, explained that he purposefully narrated the novel in satire to the Russian Revolution, Orwell writes:

I intended it primarily as a satire on the Russian revolution. But I did mean it to have a wider application in so much that I meant that that kind of revolution (violent conspiratorial revolution, led by unconsciously power-hungry people) can only lead to a change of masters. I meant the moral to be that revolutions only effect a radical improvement when the masses are alert and know how to chuck out their leaders as soon as the latter have done their job. The turning-point of the story was supposed to be when the pigs kept the milk and apples for themselves. If the other animals had had the sense to put their foot down then, it would have been all right ("Animal Farm...", 2013).
Napoleon deceives the other animals from the truth that he is altering the original vision of Animal Farm. He kills anyone who rebels against him or does not agree with him. And keeps the animals working harder on building the windmill, and the farm. Keeping the animals busy with an unending labor is just a technique for keeping them busy, so as not to be able to, or free enough to think what is happening to them or their lives. And animals should praise him for anything good happening to them. Napoleon's character does not change in the novel, he remains cruel and greedy, and always turn things his way. He gets worse on wanting more and becoming even more power-hungry because of his never-ending greed (Lacy, n.d.).

In Animal Farm, the pigs are like the sneaky politicians. They both convey the use of deceptive language to gain control over people. Politician's main goal is to lead the people of their country, just as the pig's goal is to lead their farm (Weir, n.d.).

The animals rebelled against Mr. Jones to be free and rich, to have their productions for themselves and above all to build a utopian society. They sought after a classless society, but what reality and the novel shows us in conclusion is the transformation of this utopian dream into a dystopian reality (Jahangeer, 2017).

The last scene of the novel gives a significant message to the readers concerning revolutions. The animals come to a situation worse than Mr. Jones' day. The pigs are just like human beings. As we read at the end of the novel:

Twelve voices were shouting in anger, and they were all alike. No question, now, what had happened to the faces of the pigs. The creatures outside looked from pig to man, and from man to pig, and from pig to man again; but already it was impossible to say which was which (Orwell, Animal Farm, 2013, pp. 92,93).

The animals here are totally disappointed and their dream to build a classless and equal society is crashed by the pigs. They cannot distinguish between the pigs and human beings. Here they mean their behaviors and habits are just like humans. They are cruel, greedy, careless, and corrupt just like men. When Old Major in chapter one discovered the principle of Animalism, he tells them to never adopt human vices, but at the end the pigs are just like humans in a way that it is impossible to differentiate between them. So the message here is that revolution is not the right solution to build a classless and equal society especially when the working class are naïve. There 
can be other ways but it is not revolution as it leads just to change the name and face of the people in power.

\section{CONCLUSION}

George Orwell is a great political writer and he wrote one of the most famous allegorical novels about revolution and Russian revolution. Revolution is considered by many people as a way to get rid of a tyrannical government and build a better one. But history proved that mostly there is a short period of time of happiness and success after revolution which is called honeymoon period. This period is very short and day by day life would go toward a worse situation than before revolution. Animal Farm as a great novel by Orwell very well depicts this way of transformation. By the end of the story the Animal Farm is no longer the utopian place that the animals dreamed to have. The greedy and corrupt pigs destroy their dreams and change the farm to a dystopia. The pigs adopt all the human vices in a way that it would be impossible to differentiate between the pigs and the men. At the end we realize that revolution is not the right way to change dictators and build a democratic and classless society, as the result would be only a change in the masters. That is why the animals are disappointed at the end of the novel and they say nothing about another revolution.

\section{REFERENCES}

Animal Farm: What Orwell really meant. (2013, July 11). Retrieved May 16, 2018, from nybooks. com: http://www.nybooks. com/articles/2013/07/ 11/animal-farm-what-orwell-really-meant/

Collapse of Animal Farm and the dream of revolution. (2004, June 17). Retrieved from http://discoverliterature.blogspot.com: http://discoverliterature.blogspot.com/2013/06/mahmut-deniz17-june-2004-collapse-of.html

How effective is Old Majors speech: Animal Farm. (n.d.). Retrieved from https:// studytiger.com: https://studytiger.com/essay-how-effective-isold-majors-speech-animal-farm/

How is Marxism portrayed in Animal Farm. (2013, January 20). Retrieved from www.bartleby. com: https://www.bartleby.com/ essay/How-IsMarxism-Portrayed-in-Animal-Farm-P3LXV 43VJ

Plot. (n.d.). Retrieved from https://www.bbc.com/: https://www.bbc.com/bitesize/guides/z9w7mp3/ revision/1

Revolutions...What is the primary cause. (2015, February 8). https://blog. uwgb.edu. Retrieved from https:/uwgb.edu: blog.uwgb.edu/revolutions/revolutions-what-is-the-primary-cause/

Bartleby. (2018). How Is Marxism portrayed in 'Animal Farm' by George Orwell. Retrieved
April 14, 2018, from bartleby.com: https:// www.bartleby.com/essay/How-Is-MarxismPortrayed-in-Animal-Farm-P3LXV43VJ

Bartleby. (n.d.). Bartleby.com. Retrieved May 16, 2018, from How effective is Old Major's speech: Animal Farm Essay: https://www.bartleby.com/ essay/How-effective-is-Old-Majors-speechAnimal-P3CAHN4KTJ

BBC. (n.d.). Animal Farm- plot summary. Retrieved May 16, 2018, from BBC.com: https://www.bbc. com/education/guides/z9w7mp3/revision

BBC. (n.d.). Mr. Jones. Retrieved May 16, 2018, from BBC.com: https://www.bbc.com/education/guides/zqxhn39/revision/6

Bin Uzayr, S. (2013, July 05). Retrieved from www.counterpunch.org: https://www.counterpunch.org/2013/07/05/on-the-nature-of-revolutions-and-protests/>.

Brinton, C. (1965). The anatomy of revolution. New York: Prentice Hall.

DeFronzo, J. (2018). Revolutions and revolutionary movements. n.d.: Routledge.

Deniz, M. (2004, June 17). Collapse of Animal Farm and the dream of revolution. Retrieved April 14, 2018, from Discover Literature: http://discoverliterature.blogspot.com/2013/06/mahmutdeniz-17-june-2004-collapse-of.html

Hannah, A. (1962). On revolution. New York: Penguin Books.

Huntington, S. P. (2006). Political order in changing societies. London: Yale University Press.

Jahangeer, A. (2017, December 2). Marxist analysis of "Animal Farm". Retrieved April 14, 2018, from academia.edu: https://www.academia.edu/ 19616590/Marxist_Analysis_of_Animal_Farm_

Johnson, B. (n.d., n.d. n.d.). Retrieved from https://freebooksummary.com: https://freebooksummary.com/animal-farm-by-george-orwell-anovel-depicting-how-animal-lives-in-englandwere-full-of-misery-and-slavery-27631

Johnson, B. (n.d.). Retrieved May 16, 2018, from https://freebooksummary.com: https://freebooksummary.com/animal-farm-by-george-orwell-anovel-depicting-how-animal-lives-in-englandwere-full-of-misery-and-slavery-27631

Lacy, G. (n.d.). Animal farm character analysis of Napoleon. Retrieved May 16, 2018, from essay. uk.com: http://www.essay.uk.com/coursework/ animal-farm-character-analysis-of-napoleon.php

Lenin, V. (1920). Left-wing" communism: An Infantile disorder. New York: International Publishers.

Letemendia, V. C. (1992). Revolution on Animal Farm: Orwell's neglected commentary. Journal of Modern Literature, 18, 127-137. Retrieved May 18, 2018, from http://www.jstor.org/stable/ 3831551

Mandel, E. (1989). The Marxist case for revolution today. Socialist Register, pp.159-184. 
Napoleon. (n.d.). Retrieved May 16, 2018, from BBC.com: https://www.bbc.com/education/ guides/zqxhn39/revision/3

Neitzel, L. (2018). What is revolution: n.d.: Columbia: Columbia University. Retrieved from www.columbia.edu: http://www.columbia.edu/ $\mathrm{cu} /$ weai/exeas/asian-revolutions/pdf/what-isrevolution.pdf

Orwell, G. (2013). Animal farm. London: Alfred A. Knopf.
Orwell, G. (2013). Animal farm. UK: Alfred A. Knope.

Stewart, F. (2002). Root causes of violent conflict in developing countries. BMJ, 324, 342-5.

Venter, J. C. (2015). A deconstruction of the term "revolution". koers, 1-10.

Weir, M. (n.d.). Retrieved from https://www.academia.edu: https://www.academia.edu/31619558/ Animal_farm_paper 